\title{
Defining management: Business schools, consultants, media
}

Lars Engwall, Matthias Kipping \& Behlül Üsdiken, Defining management: Business schools, consultants, media, Routledge: New York, 2016. 318 pp. ISBN: 9780415727884 (pbk)

Research and teaching in business studies have justifiably been criticised for being ahistorical (see, for example, Rowlinson et al., 2014). A quick overview of the curricula in some of the highest ranked business schools in our home countries, the United Kingdom and Finland, reveals almost a complete absence of business history and related topics. Indeed, the missions of many business schools today seek to educate business managers whose jobs are to strategise, organise and brand, looking to the future to make a difference. These activities are typically based on reinventing and reframing 'old' organisational forms, practices or perhaps a public image into something that at least appears 'new'. Management consultants, on the contrary, have made it their business to rename and reinvent tools and techniques. When a company, hospital, university or even a nation state needs to reorganise, consulting firms start making money. And so do business media (such as publishers and the business press), well-oiled machines producing academic guidebooks for those managing these change processes. As management scholars, we earn our livelihoods from reinventing business. We adopt concepts either from our own field or borrow them from other fields, re-label, apply them and then claim them within the jurisdictions of our discipline. We make our impact through inventing and reinventing business language and concepts.

It is the business of business schools, consultants, media and practising managers to pave the way for new business opportunities and jargon. In doing so, we tend to relegate the history of management to the past. Yet this is exactly why we need such a well-researched book like Defining Management (Engwall et al., 2016) - to remind us of our collective struggles in gaining legitimacy in management education, consulting and publishing. Defining Management is a timely reminder that the 'rise and rise' of business schools was not inevitable. When management education emerged pre-World War I, it evolved from vocational schools of commerce that were quite different from the institutions associated with training national élites (Engwall et al., 2016). The writers remind us that not every country followed the same trajectory in developing their institutional strata of management education. Although it is a familiar story (see Augier and March, 2011; Khurana, 2007), the dominance of US management education, consulting and business media is not the whole story. The evolution of business schools did not occur in a vacuum, but through interactions with other major actors and contestants in the field, namely business consultants and business media (defined by Engwall et al. (2016) as publishers, business press and academic journals). 
It is the business of business schools, consultants, media and practising managers to pave the way for new business opportunities and jargon. In doing so, we tend to relegate the history of management to the past. Yet this is exactly why we need such a well-researched book like Defining Management (Engwall et al., 2016) - to remind us of our collective struggles in gaining legitimacy in management education, consulting and publishing. Defining Management is a timely reminder that the 'rise and rise' of business schools was not inevitable. When management education emerged pre-World War I, it evolved from vocational schools of commerce that were quite different from the institutions associated with training national élites (Engwall et al., 2016). The writers remind us that not every country followed the same trajectory in developing their institutional strata of management education. Although it is a familiar story (see Augier and March, 2011; Khurana, 2007), the dominance of US management education, consulting and business media is not the whole story. The evolution of business schools did not occur in a vacuum, but through interactions with other major actors and contestants in the field, namely business consultants and business media (defined by Engwall et al. (2016) as publishers, business press and academic journals).

The key rationale for this text lies in the lifetime work of the three authors who have studied, together and independently, the origins, developments and spread of management ideas through education, consulting, the business press, books and academic journals. Engwall et al. (2016) have succeeded in producing a compendium of defining moments in the evolution of management ideas and entities largely marked out by two world wars and industrial revolutions in the United Kingdom and United States. The authors outline their contributions in Defining Management as historical, comparative and integrative. This text includes a linear collection of dates and facts about the three influential 'management authorities' and the evolution of their legitimation and reputation projects. The common denominator of this book and the authors' earlier published works is the criticism of an ahistorical, acontextual, noncomparative and overly US-centred understanding about the origins of management thought and practice.

For European scholars who have studied the business school field in Finland (Kettunen, 2013) and the United Kingdom (Davies, 2014), the argument that a more comparative, multicountry perspective is needed is naturally compelling. This book is also interesting reading for us because both Finland (an example of a country that followed the German Handelschochschule tradition in management education) and the United Kingdom (the European outlier that pursued the US business school model by integrating commercial education into universities, but only latterly in the ancient Oxford and Cambridge élites) are discussed in detail as a part of the broader development trajectory. Defining 
Management includes insights into an extensive range of countries with excellent citations throughout and convenient beginning of chapter summaries.

Compared with its closest peers such as Khurana's (2007) and Augier and March's (2011) historical publications, Defining Management richly extends our understanding of the evolution of business schools and management education beyond a predominantly US perspective. In comparison, Defining Management is neatly designed as a modular and chronologically structured reading experience (written in textbook style but without activities). Boxed mini cases in the text relating to individuals and institutions offer valuable vignettes, for instance, on Peter Drucker and Philip Kotler, Harvard's case method, INSEAD, AACSB, Elsevier, and Thomson Reuters. The book takes into account events not only within business schools but also in neighbouring fields. As the authors explain at the outset, you can read Defining Management either chapter by chapter sequentially prior to World War I, during the inter-war years, post World War II or by selecting the chapters that discuss the history of business schools, consulting and media separately. We found the tables on management publications particularly interesting. Several sections on management consulting firms are sceptical about their value in tracing developments from engineering, accounting and audit, to HR, marketing, strategy and general management consulting. The authors emphasise the enabling roles of associations, conferences and the Ford Foundation in internationalising US management ideas. They compare how managers have been educated over time in different countries.

We especially enjoyed reading quirky snippets that made history come alive with valuable micro-level perspectives on key actors involved in the development of the field. These include fascinating comments about Galileo consulting for the Venice Arsenal, Pacioli's bookkeeping, Frederick Taylor as the 'grandfather' of management consulting and Lillian Gilbreth as the 'first lady of management'. We learn about Isabella Beeton's best seller on managing household staff, Bedaux which was the largest consulting firm in the 1930s, McKinsey's dissemination of the M-form and its highly influential alumni network, as well as Arthur Andersen himself and Enron. We discover that Cambridge University Press is the world's oldest and Oxford University Press the largest. Who knew that Pearson began as a Yorkshire construction and engineering firm or that Frederick Taylor was born into a wealthy family and chose to start working life as an apprentice? It is also curious to note that the business schools Hult and BI Norway were created by management consulting firms ... and that 'managing' is derived from mid-16th century Italian 'maneggiare' - handling horses.

In our view, Chapter 3 is the most important theoretically, with its specific focus on institutional theory and historical organisation studies (see Clark and Rowlinson, 
2004; Kipping and Üsdiken, 2014; Maclean et al., 2016; Rowlinson and Hassard, 2014). We suggest that this book makes three primary contributions. First, Defining Management gives an idea how theoretically informed history may be written without overly compromising the traditions of the study of history. Second, the text makes apparent the value of history for understanding micro-level processes of institutionalisation. Third, as a conclusion, Engwall et al. (2016) offer an institutionalist explanation for the expansion of management. More than a story of professionalisation (as in Khurana, 2007) or scientisation (as in Augier and March, 2011), Defining Management presents insightful narratives of how business schools, consultants and media gradually gained legitimacy through copying current templates and organisational forms in their particular institutional and national environments. Obviously, these templates varied from one country to another, with pioneers in the United States being more open to the establishment of university-based professional schools. Germany followed the Handelshochschule model in developing the science of Betriebwirtschaftslehre (BWL), that is, business economics. After they gained acceptance, 'these fields were then associated with broader societal logics and their related discourses to cement their definitional power' (Engwall et al., 2016: 281).

Despite many years of collaboration, this is the first time the three authors have published a book together and they undoubtedly combine a vast amount of expertise. Clearly, the authors are established authorities themselves. Lars Engwall has a life-time's research outputs on industry analysis and management knowledge mobilisation (e.g. Engwall and Kipping, 2004). Matthias Kipping has written extensively on business history and management consulting in disseminating US models. Behlül Üsdiken is a scholar of the history of management thought and education, with a particular interest in convergence and fragmentation in the interplay between centres (such as the United States) and peripheries (e.g. Üsdiken, 2014).

The origins of Defining Management can be traced back to Engwall et al.'s (2001) European Union (EU) project report on the Creation of European Management Practice (CEMP). This resulted in multiple publications (e.g. Engwall and Kipping, 2006). CEMP explored the co-evolution of management practice with academia, media and consulting in terms of carriers, content and diffusion. The report concluded that consultants and a few media conglomerates were the most advanced in terms of acting on a global level. The report's authors observed that the business school was being characterised by the gradual blurring of the boundaries of business education, consulting, and media fields. For instance, business schools were offering consulting, and media organisations were supplying executive education and influencing business school rankings (see Engwall et al., 2001). Over 15 years since the EU report, Defining Management suggests further international commoditisation has occurred 
with greater blurring of boundaries. For example, executive education is provided by business schools and consultancies and there are polymathic management academics who bridge all three domains as consultants, authors and media commentators.

On the one hand, Defining Management offers few new insights for readers who are already quite familiar with the authors' previous outputs. On the other hand, this book offers an enlightening and absorbing reading experience for business school students, faculty, consultants and publishers who are unfamiliar with these three professors who are based in Sweden, Canada and Turkey, respectively. Indeed, this management history has the power to explain some of the path dependencies and struggles that business scholars and students experience daily within the university community and job markets with respect to people from other professional, disciplinary and educational backgrounds. Having said this, we would like to point out that a great deal of water has run under the bridges of the three 'management authorities' explained in the text since the early 2000s which is the focus of the last period presented. There are substantive updates that could have been made immediately prior to publication about developments in the 21 st century.

Our main criticism is that Defining Management lacks perspectives of less established actors such as Millennials, digital natives, non-professorial scholars, management consultants who are not yet partners, and newer and aspiring journal editors who could have provided contemporary commentaries. In 2017, we are talking about digital, virtual and networked organisational forms, and the internet of things. In the light of recent rapid changes in our industry, we believe that Defining Management could have benefited from the inclusion of a chapter on recent history as it is currently unfolding, particularly with reflections based on the authors' historical analyses. For example, this book lists extensive mergers and acquisitions and shakeouts among publishers and management consultants, yet it ignores consolidations in the business school field (e.g. Hult's 'operational merger' with Ashridge in the United Kingdom and Thunderbird being assimilated into Arizona State University in the United States).

Defining Management also neglects influential business journalists like Della Bradshaw at the Financial Times who launched its business school rankings (Bradshaw, 2015), and the role of business school deans in the evolution of the field. In addition, the increasingly pervasive impact and interdisciplinary management research agendas (see Beech et al., 2017; Lejeune et al., 2015) are not mentioned in Defining Management. The creation of entities such as Deloitte University and Deloitte University Press, the rise of Pearson (including Pearson Business School), for-profit business school scandals (Vara, 2016), and top management academics with various conflicts of interest as academic journal editors, advisers 
to management consultancies and the media would provide further interesting mini case studies for Engwall and his collaborators to explore in the next edition. Regulators also need to be examined more closely in the field, a topic Engwall continues to explore (Engwall and Morgan, 1999; Engwall et al., 2018).

In light of contemporary debates about fake news, growing nationalism and antiestablishment tendencies and declining MBA student numbers (The Economist, 2016), Engwall et al.'s (2016) assumption that business schools, management consultants and the business media are still the authorities on management is increasingly open for debate. Management ideas, models and practices are now generated and transferred by influential stakeholders such as tech entrepreneurs, BBC News, Bloomberg, CNN, Huffington Post, Reuters, Sky, TED talks, Wikipedia, YouTube and the twittersphere. Business school academics are plugged into Google Scholar, ResearchGate, The Conversation and digital platforms. Meanwhile, the web sites of global management consulting firms like McKinsey\&Company focus on wider issues than just at the firm level such as digital disruption, employment and growth, long-term capitalism, urbanisation, women and emerging markets. Hence, we find it worth questioning what traditional management authorities mean to Gen $\mathrm{Z}$, whether management is acceptable in a context of the gig economy, high levels of selfemployment, the death of newspapers and an increasing concentration on entrepreneurship in business schools. Will the automation of jobs translate into new organisational forms of Taylorism? In conclusion, conceptually Engwall, Kipping and Üsdiken have framed the mutually legitimizing fields of business schools, management consulting and business media systematically into different logics and time scales economically, politically and socially. Overall, what we can agree on in reviewing this highly informative book, however, is that the authors' and our attempts at 'defining management' are work in progress. As management educators and researchers, what keeps us in the "business school "business"' (Pfeffer and Fong, 2004 ) is its dynamism, the community of scholars and the aspirations that in our work with practitioners we can contribute to 'public debate over solutions to social challenges' (Garrett et al., 2016: 8). A dynamic, interactive web site to complement this book would be very helpful to remain updated on new developments. In the peculiarly post-truth age we inhabit since this publication was issued, it is reassuring to access reliable evidence about how the fields we inhabit have been shaped. This enables us to appreciate struggles in how management is constantly being defined, redefined and refined. Right now, Harvard Business School's senior faculty are seriously reflecting on the limitations of its signature historic case method (Hill, 2017), glaring conflicts of interest, waning intellectual leadership and inequalities inherent in the School's business model (The Economist, 2017). Our critical Management 
Learning debates will also continue to inform historical, comparative and integrative approaches for future editions of Defining Management.

\section{References}

Augier M, March JG (2011) The Roots, Rituals, and Rhetorics of Change: North American Business Schools After the Second World War. Stanford, CA: Stanford University Press.

Beech N, Bartunek J, Mason K, et al. (2017) Impact and management research: Exploring relationships between temporality, dialogue, reflexivity and praxis. British Journal of Management 28(1): 3-13.

Bradshaw D (2015) A look back at 20 years of business education in the FT. The Financial Times, December 6.

Clark P, Rowlinson M (2004) The treatment of history in organization studies: Towards a 'historic turn'? Business History 46(3): 331-352.

Davies J (2014) Hybrid upper middle manager strategizing practices: Linking archetypes and contingencies in the UK Business School Deanship. PhD Thesis, Coventry: Warwick University.

Engwall L, Alvarez JL, Amdam RP, et al. (eds) (2001) The Creation of European Management Practice (CEMP): Final Report. Targeted Socio-Economic Research Programme (TSER). Luxembourg: Office for Official Publications of the European Communities.

Engwall L, Kipping M (2004) Introduction: The dissemination of management knowledge. Management Learning 35(3): 243-253. Crossref.

Engwall L, Kipping M (2006) Management education, media and consulting and the creation of European management practice. Innovation: The European Journal of Social Science Research 19(1): 95-106.

Engwall L, Kipping M, Üsdiken B (2016) Defining Management: Business Schools, Consultants, Media. New York: Routledge.

Engwall L, Morgan G (eds) (1999) Regulation and Organisations: International Perspectives. London and New York: Routledge.

Engwall L, Grünberg J, Pallas J, Sahlin K (2018) Corporate Governance in Action: Regulators, Market Actors and Scrutinizers. London and New York: Routledge.

Garrett G, Saloner G, Nohria N, et al. (2016) The achievements and future of business education. Journal of Applied Corporate Finance 28(3): 8-25.

Hill A (2017) Harvard and its business school acolytes are due a rethink. The Financial Times, May 8.

Kettunen K (2013) Management education in a historical perspective: The Business School question and its solution in Finland. PhD Thesis, Oulu: University of Oulu.

Khurana R (2007) From Higher Aims to Hired Hands: The Social Transformation of American Business Schools and the Unfulfilled Promise of Management as a Profession. Princeton, NJ: Princeton University Press.

Kipping M, Üsdiken B (2014) History in organization and management theory: More than meets the eye. Academy of Management Annals 8(1): 535-588.

Lejeune C, Davies J, Starkey K (2015) The impact of the impact agenda. Global Focus 9(2): $44-47$.

Maclean M, Harvey C, Clegg SR (2016) Conceptualizing historical organization studies. Academy of Management Review 41(4): 609-632.

Pfeffer J, Fong CT (2004) The business school 'business': Some lessons from the US experience. Journal of Management Studies 41(8): 1501-1520.

Rowlinson M, Hassard J (2014) History and the cultural turn in organizational studies. In: Bucheli M, Wadhwani RD (eds) Organizations in Time: History, Theory, Methods. Oxford: Oxford University Press, pp. 147-168. 
Rowlinson M, Hassard J, Decker S (2014) Strategies for organizational history: A dialogue between historical theory and organization theory. Academy of Management Review 39(3): 250-274.

The Economist (2016) Nothing special: MBAs are no longer prized by employers. The Economist, June 13.

The Economist (2017) From great to good. A confidential memorandum to the senior faculty of Harvard Business School. The Economist, May 4.

Üsdiken B (2014) Centres and peripheries: Research styles and publication patterns in 'top' US journals and their European alternatives, 1960-2010. Journal of Management Studies 51(5): 764-789.

Vara V (2016) The sorry legacy of the for-profit college boom. The New Yorker, May 16. 